\title{
INCONSISTENT APPLICATION OF INTERNATIONAL FINANCIAL REPORTING STANDARDS
}

\author{
Vladimir Obradovic* \\ Faculty of Economics, University of Kragujevac, Kragujevac, Serbia
}

The transformation of the International Financial Reporting Standards (IFRS) into a single global language of financial reporting is well under way and followed by a problem of their inconsistent application from country to country, with negative consequences for the global comparability of financial statements. Starting from this, the main purpose of this paper is to give an overview of the main causes of the diversity of financial reporting practices between those countries declaring themselves to be the followers of the IFRS, as well as to identify the ways of overcoming this diversity. Applying the qualitative research methodology, it has been found that the flexibility of the IFRS provisions, which is inevitable in many cases, modifications in their incorporation into national regulatory frameworks and the diversity and unequal effectiveness of national mechanisms for their enforcement and the supervision of their implementation stand for the main causes of inconsistent accounting practices. In order to reduce the inconsistency, national financial reporting regulators should increase their engagement and coordination among themselves, and the International Accounting Standards Board should make additional efforts, which should primarily be focused on the global promotion of the fundamental basis of the IFRS.

Keywords: financial reporting, International Financial Reporting Standards (IFRS), International Accounting Standards Board (IASB), inconsistent application

\section{JEL Classification: M41}

\section{INTRODUCTION}

Under the influence of business globalization, especially the globalization of capital markets, the issue of the globalization of the financial reporting standards has assumed greater importance. Bearing in mind the undisputed belief that "differences in accounting practices act as a barrier to capital flow"

\footnotetext{
* Correspondence to: V. Obradovic, Faculty of Economics, University of Kragujevac, D. Pucara 3, 34000 Kragujevac, Serbia; e-mail: vobradovic@kg.ac.rs
}

(Saudagaran, 2009, 2.34), it is obvious why a single set of high quality global financial reporting standards that would be applied in a consistent manner in all countries of the world is something which "global capital market participants have long been hoping for" (Cabrera, 2008, 36). In recent years, the need for such standards has become particularly noticeable, because they would enable an easy and accurate comparison of the financial position and performance of companies from different countries by investors, creditors and other users of financial statements. 
Today, the International Financial Reporting Standards (IFRS) issued by the International Accounting Standards Board (IASB) represent the most important and widespread financial reporting standards worldwide and have a great potential to become universal at the global level. The conversion of the IFRS into a single set of global standards is already in progress, which is confirmed by the fact that the number of countries following them is continuously growing, while many countries that still have their own standards (such as the USA) intend, in the near or distant future, to adopt them. Worldwide, the IFRS are regarded as standards of very good quality (Epstein, 2009, 27), i.e. as „a satisfactory global platform with the opportunity for further advances" (PricewaterhouseCoopers, 2007a, 3), while the fact that they have been developed taking into consideration viewpoints from different parts of the world inspires further confidence in them. The IFRS offer great opportunities to improve the transparency and comparability of financial statements globally, with positive effects on the development and integration of capital markets, and global economic growth and development in general. Its setter, the IASB, has managed to acquire the status of the world's most respected institution for the development of financial reporting standards.

However, as a private sector body, the IASB does not have the ability to directly impose its standards on companies because it has no authority over any auditor and preparer of financial statements or regulator of financial reporting (Stevenson, 2008, 34). In this respect, its position is quite different from the position of national standard-setters who operate within a national regulatory framework and have clearly defined authorities. The IASB, therefore, has no other choice but to develop standards as a public good and put them at the disposal of any country or company that wants to adopt and apply them, at the same time encouraging national regulators to accept them, in line with its abilities and influence.

In addition, since the IASB has no direct authority over preparers and auditors of financial statements or national regulators of financial reporting, it is unable to ensure a consistent application of the IFRS in all countries which declare themselves as the followers of the IFRS. It is the very problem of the inconsistent application of the IFRS around the world that has become increasingly noticeable in recent years. Unlike previous decades, when overcoming the differences between national standards was the central issue, nowadays it is the inconsistent application of the same standards - the IFRS - that is more and more often identified as a problem.

Namely, cultural and other environmental factors may result in different interpretations of the same standards and different levels of enforcing those standards in various countries, with negative consequences on the comparability of financial statements (Doupnik \& Perera, 2007, 103). Adopting the IFRS in a country is one thing, while their implementation is quite another. The mere fact that a country has adopted the new accounting principles and rules does not guarantee their quick, effective and full implementation, because the "old mentalities and ways of doing things have to be replaced, which might take a generation" (McGee, 2006, 202). With this in mind, the statement that the "convergence of accounting standards may be easier than overcoming the cultural differences and perspectives determining the interpretation and application of the IFRS" (Deloitte, 2008, 4) seems to be quite correct. Without a consistent application of the IFRS, there can be no single global language of financial reporting. Global standards applied in an inconsistent manner are only global in their name (Ernst \& Young, 2012, 1).

The research subject of this paper is the diversity of the financial reporting practices of the countries declaring themselves to be the followers of the IFRS, and the main purpose of the research is to give an overview of the main causes and ways to overcome this diversity. In the research process, the following hypothesis shall be tested: The features of the very IFRS, the procedures of their incorporation into national regulatory frameworks and the weaknesses of national incentive mechanisms create a room for diversity in the application of the IFRS worldwide.

The previously formulated hypothesis shall be tested using the qualitative research methodology based on the descriptive analysis. Starting from the relevant literature, which includes a theoretical discussion and 
the analysis of the specific cases, general conclusions about this problem shall be derived. The method of induction will have particular importance, because, using this method, general conclusions about the characteristics of the IFRS shall be drawn on the basis of the provisions of individual standards; on the other hand, general conclusions about the shortcomings of the mechanisms of converting the IFRS into national standards and the mechanisms to ensure their consistent application shall be drawn, based on the examples of some countries. The method of comparison, based on the comparison of the features of the regulatory regimes and financial reporting practices of different countries, will also be used in the paper.

The following three sections of the paper are devoted to the main causes of variations in the financial reporting practices of the countries following the IFRS. The room for variations in practices, which is left by the flexibility of the IFRS themselves, is the subject of consideration in the first section; the factors of the occurrence of the national versions of the IFRS are considered in the second section, while the weaknesses of national incentive mechanisms are the subject of consideration in the third section. The fourth section, being the last one in the paper, points to the possibilities of reducing variations in the application of the IFRS.

\section{THE FLEXIBILITY OF IFRS}

The IFRS are flexible by their nature and, as such, leave considerable room for a choice of accounting practices. The factors of an inconsistent application of the IFRS in practice associated with the characteristics of the IFRS themselves are (Nobes, 2013, 91-93):

- gaps in the standards,

- open options in the standards,

- hidden options in the standards and imprecise criteria for the recognition of the elements (items) of financial statements, and

- the need for a judgment in measuring financial statement items.
Although the IASB continually develops new standards and improves the existing standards in accordance with changes in business practice, certain gaps in standards, in terms of the lack of solutions to some specific accounting problems, are practically impossible to avoid. The IASB itself is aware of it, and, in its standard dedicated to the accounting policies, changes in accounting estimates and errors (IAS 8), points out that, in the absence of standards or interpretations dealing with a specific transaction or event, the preparers of financial statements should use their judgment and rely on other (national) standards and interpretations devoted to similar problems, and the IASB's conceptual framework.

An example of a standard that makes considerable room for a wide range of accounting practices is IFRS 4 (Pacter, 2013, 55), which only deals with the general issues of accounting for insurance contracts, without offering solutions to all the problems in this area. Additionally, IFRS 6 leaves plenty of room for different solutions to the accounting problems occurring in the oil and gas industry.

Coping with gaps in the IFRS, the preparers of financial statements may decide to continue with a long-term national tradition, i.e. a tradition established prior to the adoption of the IFRS. In any case, they have a maneuvering space that could have negative consequences for the global comparability of financial statements. National regulators could also fill the gaps in the IFRS by creating standards that would supplement the IFRS. That is exactly what the Australian standard setter did by releasing its own standard dealing with some issues of insurance contracts not addressed in the IFRS, as well as with other issues specific to the national environment (PricewaterhouseCoopers, 2010, 141). A possibility that national standard setters around the world solve the problems the IASB has not addressed in different ways poses an additional threat to the global comparability of financial statements.

One of the important features of the IFRS is the existence of open options, i.e. different possibilities for the accounting treatment of the same accounting problems, which is an important source of differences in the practical application of the IFRS around the 
world. The typical examples of situations in which the current IFRS offer options are determining the value of end inventories and the cost of inventories disposed, where the choice between the FIFO method and the average cost method is allowed, and the measurement of property, plant, equipment and certain intangible assets after the initial recognition, where a choice between the historical cost model and the fair value model is allowed. When making a decision on the choice of a particular method from a set of offered methods, the tradition established before the adoption of the IFRS comes to the forefront again. For example, based on the rooted tradition, it can be expected that British companies will be using the FIFO method of accounting for inventories, and German companies will be applying the average cost method (Nobes \& Parker, 2010, 160-161).

Generally speaking, the number of open options in the standards has a declining tendency (Alfredson et al, 2007, 33) due to the gradual elimination of the previously established options. However, the development of the IFRS makes new options emerge, and the most recent example is an increase in the number of the options for measuring investments in subsidiaries, associates and jointly controlled entities in separate statements after changes to IAS 27, made in August 2014. Namely, the third option - measurement using the equity method - was added to the two already available options (measurement at cost and measurement at fair value) (Deloitte Global Services Limited, 2014).

A specific category of open options is a set of options offered by IFRS 1 , which deals with the problem of companies' transition from national standards to the IFRS. Among other things, this standard allows preparers of financial statements to choose between the revaluation of goodwill and taking its previous amount (i.e. the amount determined by the preexisting national standards) without any revaluation, in the preparation of the first statements based on the IFRS. As national standards significantly differ in terms of accounting for goodwill and as the first financial statements based on the IFRS represent a starting point for a series of subsequent statements, it is clear that the options related to the amount of goodwill in the first statements based on the IFRS may have a negative impact on the global comparability of financial statements in the long term.

Another specific category of open options is one stemming from the flexible effective dates of new or revised standards. Namely, when publishing each standard, the IASB determines its effective date, in the form of the statement that "an entity should apply the standard for annual periods beginning on or after January 1, 20XX", whereby companies (entities) are usually allowed to apply it before the established deadline. For example, the IASB replaced IAS 14 with IFRS 8 at the end of 2006. The effective date for IFRS 8 was 1 January 2009, but there was also a possibility of an earlier adoption. This practically means that two different standards dealing with the same accounting problem (segment reporting) - IAS 14 and IFRS 8 - existed simultaneously in 2007 and 2008, and it was possible for companies to apply either of them. At the beginning of 2007, the IASB revised the standard dedicated to borrowing costs (IAS 23), with 1 January 2009 as the labeled effective date of the revised version of the standard and a possibility of an earlier application, which means that the two versions of the same standard coexisted until the mentioned deadline. Flexible deadlines for adopting standards have essentially the same effect as the options in the standards themselves. Although the period of the coexistence of two alternative standards or two versions of the same standard (the old and the new ones) does not last long (no more than 2-3 years), the continual creation and improvement of standards bring new cases of coexistence and, therefore, generate new sources of differences in the practical application of the IFRS not only globally but also at the level of one particular country.

In addition to open options, the IFRS contain many hidden options and imprecisely defined criteria for the recognition of the elements of financial statements (assets, liabilities, revenues and expenses), which further increases a possibility for preparers of financial statements to make a choice. Analyzing the IFRS effective in 2013, C. Nobes $(2013,95)$ identified a large number of the situations in which preparers of statements face hidden options or imprecise criteria for recognition. Some of these examples, updated in 
accordance with the subsequent changes to the IFRS, are:

- the determination of the materiality (significance) of certain items (IAS 8);

- the classification of leases as finance and operating depending on whether there is a transfer of "substantially all the risks and rewards" from the lessor to the lessee, without numeric criteria (IAS $17)$;

- the determination of the functional currency (IAS 21);

- the identification of subsidiaries on the basis of the "power to govern" (IFRS 10), of associates on the basis of the "significant influence" (IAS 28) and of joint ventures on the basis of the "rights to the net assets of the arrangement" (IAS 28);

- the recognition of provisions based on the "probability of an outflow of resources" (IAS 37); and

- the capitalization of development costs (IAS 38).

The above-mentioned situations as well as a number of other unmentioned ones are the unavoidable consequences of the nature of accounting, which makes it impossible for standards to provide an answer to each possible question. They also result from the IASB's quite a correct orientation towards the principles-based standards, which are based on the position that the purpose of standards is to define the space given to accountants to make decisions within, i.e. to exercise their judgments that remain an integral part of accounting and financial reporting. Since the IFRS do not contain clear and precise criteria for the accounting treatment of a number of transactions and events, it is essential that preparers of financial statements perceive their economic substance and decide on the proper treatment on the basis of their judgments. The manner in which preparers of financial statements interpret the economic substance of transactions and events largely depends on the environment in which they live and work, that is, on the values of the society which they belong to. For example, there is a study revealing that, under the influence of differences in cultural values, German accountants interpret the word "probable", which is common in the IFRS, with more caution than U.S. accountants (Doupnik \& Richter, 2004, 1-20).

Accounting judgments are not only related to the recognition of the positions of financial statements, but they are also of utmost importance in determining their values on the basis of the IFRS. In fact, in all situations where exact and objective criteria for measuring do not exist, accountants' reasonable judgments are the only solution, wherein accountants from different countries exhibit different preferences, under the influence of the respective culture, tradition and tax regulations.

The depreciation of property, plants and equipment is the area in which the need for judgment is clearly visible, especially in the determination of the useful life, the estimation of the residual value and choosing the method of depreciation. Analyzing the depreciation practices of the European countries, C. Nobes and R. Parker $(2010,163)$ point out that British companies traditionally tend to have simpler depreciation regimes, which involves the application of the straight-line method, the residual value equal to zero and the useful life of 10 years, while, under the influence of tax regulations, companies in some countries of the continental Europe, traditionally utilize the accelerated depreciation method, with a tendency towards a shorter useful life. Determining the fair value of assets and liabilities also involves judgment and is considered to be a very sensitive area of financial reporting. In addition, the net realizable value of inventories, the amount of the impairment of property, plant and equipment, and the values of provisions are inevitably the subjects of estimation.

The estimated amounts in financial statements of companies from one country depend on whether the preferences for conservatism or optimism have the dominant role in that particular country. For example, if there is a prevailing tendency towards conservatism, it is more likely that companies will choose the accelerated method of depreciation, with a shorter useful life and a lower estimated residual value, and that they will measure provisions in higher amounts. 
Based on the previous observations, it can be concluded that, on the one hand, the IFRS make progress in increasing the international comparability and consistency of companies' financial statements, whereas on the other, they allow financial reporting in each country to simultaneously keep national colors, i.e. to still bear the stamp of the previous national standards. That fact is clearly reflected in the results of one empirical study focusing on the 16 accounting issues regarding which the IFRS permit variations, and where international differences existed before the adoption of the IFRS by the countries which the observed companies originate from. The study shows that the differences remained even after the transition to the IFRS, i.e. the companies kept their national traditions (Kvaal \& Nobes, 2010). The second study, focusing on the 26 open (explicit) options offered by the IFRS, reveals that the country of domicile and its previous financial reporting standards have the greatest impact on companies' accounting choices (KPMG \& von Keitz, 2006).

\section{NATIONAL VERSIONS OF IFRS}

In addition to the characteristics of the IFRS themselves, i.e. many open questions, the final answer to which should be given by preparers of financial statements, there is significant room for differences in the accounting practices of the companies following the IFRS is created during the incorporation of the IFRS into such countries' regulatory frameworks of financial reporting. The lack of the direct authority of the IASB has led to the fact that in some countries a modified version of the IFRS is applied instead of their original version published by the IASB (Alali \& Cao, $2010,79)$. In other words, in addition to the original IASB's version, there are also national versions of the IFRS, which, to a greater or lesser degree, deviate from the original one.

After the consideration of the relevant literature (IFRS Foundation, 2014; Nobes, 2013, 89-90; Nobes \& Parker, 2010, 158-159), it can be concluded that the most important reasons for the emergence of the national versions of the IFRS are:
- the modification of the IFRS provisions by the national regulator;

- a delay in the incorporation of the new or amended standards or a delay in their implementation; and

- mistakes in the translation of the IFRS.

Many countries adopt the IFRS in an indirect way, by transferring them into their own standards, with a more or less complicated procedure of approval by the applicable regulatory authority, which can be national (such as, for example, in Australia), or common for a group of countries (as it is the case of the European Union countries). In addition, the IASB's standards can be incorporated into a national regulatory framework without any modifications, which is most often the case, or modified in a certain manner in order to adapt to specific circumstances.

In some cases, such modifications only refer to the elimination of some options for the accounting treatment. For example, when incorporating the IFRS into Brazil's regulatory framework, the provisions allowing for the periodic revaluation of financial statements' positions were deleted (IFRS Foundation, 2014). The elimination of some options leads to deviations of national standards from the IFRS; however, it cannot be said that companies consistently complying with national standards derogate from the IFRS.

However, a much more serious problem for the global comparability of financial statements arises if a country or a group of countries substantially modifies the provisions of the IFRS, as the European Union did with the provisions of IAS 39. Namely, the IASB revised IAS 39 in 2003 and 2004, which caused strong reactions in the $\mathrm{EU}$, while the major objections were related to the accounting treatment of financial derivatives and hedging, and expanding the use of the fair value for the purposes of measuring financial assets and liabilities in comparison with the previous version of the same standard (Armstrong et al, 2010, 34-35). The above-mentioned objections resulted in the adoption of a modified version of IAS 39 by the European Commission (EU) in November 2004, whereby the modifications relate to the elimination of the controversial provisions regarding hedge 
accounting and the use of the fair value. These modifications made the version of the IFRS followed by the companies from the EU different from the original, i.e. the IASB's version. Later, under the pressure of the EU, the IASB revised IAS 39 once again and limited the use of the fair value only to the situations in which it can reliably be measured. The EU adopted the changes, thereby eliminating a significant difference between the original version of IAS 39 and the version of the same standard applied at the EU level.

Taking into consideration the previously mentioned facts, it is clear that the process of incorporating the IFRS into the EU regulatory framework effectively created the new - EU - standards (Tokar, 2005, 49). A favorable circumstance is that the differences between the original version of the IFRS and their versions applied by the EU companies do not really have a great practical importance, as the differences refer to the financial reporting of only a small number of companies (Pacter, 2014, 8).

The process of incorporating any new or revised standard and interpretation into the national regulatory framework is carried out differently from one country to another and has a different length. If a country does not adopt a standard or an interpretation in time, i.e. by the date the IASB marked as the effective day, there will be differences between the version of the IFRS followed in that particular country and the version followed in other countries that have completed the adoption process in time.

The Republic of Serbia (RS) belongs to those countries that have not harmonized their own financial reporting regulation with the IFRS in a sufficiently timely manner so far. Namely, the first official translation of the IFRS, including the conceptual framework and all the International Accounting Standards (IAS) but not the respective interpretations, was published in December 2003. The translation of IFRS 1 was published in January 2004; after that, there was a four-year break in the publication of the translations, during which period the IASB published six new standards entering into force in the same period (IFRS 2-7) and also revised a significant number of the existing standards (for example, in December 2003, the IASB amended IAS 2, abolishing the possibility of using the LIFO method for inventory accounting, while the revised standard came into force on 1 January 2005). Due to the lack of the activity in publishing the official translations of the new and revised standards by the authorized regulatory bodies, the version of the IFRS applied by companies in RS was significantly different from the original version. In February 2008, the new translations of the IFRS were finally published, replacing the translations of 2003 and 2004. For the first time, the translations of the interpretations were published together with the translations of the standards; yet, there was no translation of the supplementary materials (the basis for conclusions, illustrative examples, guidelines, comments and opposing views), which can be considered as a disadvantage, because the listed appendices would facilitate the understanding and implementation of the standards. In this regard, the translations of 2008 are a step backwards compared to the translations of 2003, which included the additional materials (appendices). The next version of the IFRS translations was published in October 2010, while the latest version was published in March 2014. If we take into account the fact that the IASB's standard dedicated to small and medium-sized entities, adopted in 2009, was not incorporated into the regulatory framework of RS until 2013, which means that the companies which the standard refers to (i.e. companies without public accountability) did not have an opportunity to use a simpler version of the IFRS and decrease the cost of the preparation of their financial statements, it is clear that the past activities in updating the financial reporting regulatory framework of Serbia in accordance with the IFRS changes could not be evaluated as satisfactory. So far, the publication of the official translations of the IFRS has generally run late, which means that the version of the IFRS applied in RS has generally been different from the IASB's version. It should be added that the bylaw act brought in 2009 permitted Serbian companies to use the accounting treatment that is not consistent with the provisions of IAS 21 dealing with foreign currency transactions (Bogicevic, 2013). This option was in effect until September 2014. Moreover, the National Bank of RS requires from financial institutions to apply the accounting procedures not fully compatible with the requirements of the IFRS. 
The timely adoption of new or amended standards does not automatically guarantee the timely beginning of the application of the same, as the national regulator may allow companies (all or some of them) to postpone the beginning of the application for a specific time. For example, the application of the six standards has been delayed in Taiwan (IFRS Foundation, 2014).

The translation of the IFRS from English, as the language of their original and official version, into other languages inevitably involves the risk of changing their meaning. In fact, the full equivalence of any text translation and its original version is not easy to achieve, while the risk of not conveying the meaning of the original text increases with the number of technical terms used. The IFRS contain a significant number of technical terms, which are often difficult to translate adequately. A particular problem is the provisions of IFRS that contain new concepts or deal with problems that are not fully understood or are even completely unknown in many national cultures. Even the most accurate translation of these provisions does not guarantee a complete transfer of their essence and logic. Therefore, a situation might occur, where the words, but not the concepts, may be understood (Zeff, 2007, 296).

The following three examples clearly show the extent of discrepancies in the translations of the original IFRS provisions.

According to the original version of IAS 41, an unconditional government grant related to a biological asset should be recognized as income when the company acquires a receivable on that basis, while according to the translation of the same standard into the Norwegian language, published in 2006, the recognition of income is related to the moment of a cash inflow on the basis of the grant.

In the original version of IAS 7, cash equivalents are defined as investments with a "short maturity of, say, three months", as a result of the IASB's attempt to avoid the formulation of a rigid rule. However, in the Portuguese translation, the word "say" is omitted, which turned a flexible principle into a strict rule. Therefore, in Portugal, it is harder to defend the position that an investment with a maturity of slightly more than three months is essentially a cash equivalent compared to any other country where the translation is correct.

According to the original version of IAS 19, the discount rate for pension liabilities is determined on the basis of interest rates on corporate bonds, while according to the German version of the same standard, it is determined on the basis of interest rates on industrial bonds, which are a subcategory of corporate bonds (Nobes \& Parker, 2010, 159).

The analysis of jurisdiction profiles (which are mostly, but not always, consistent with independent countries), created between June 2013 and September 2014, and published on the website of the IFRS Foundation (the entity responsible for managing, monitoring and financing the IASB), reveals that there are a significant number of jurisdictions in which the IFRS have been modified in some way. Out of the 127 analyzed jurisdictions, where at least some companies are required or permitted to use the IFRS, in 53 jurisdictions $(42 \%)$, a version different from the current IASB's version is applied due to the modifications of the IFRS provisions, delays in the incorporation of the new or amended standards, or delays in the implementation of some standards or interpretations. In three jurisdictions, the modifications only refer to the elimination of the options offered by the IFRS. The most analyzed jurisdictions in which the modified versions of the IFRS are applied (28) belong to the European Union. Modifications were also made when incorporating the IFRS for Small and Medium-Sized Entities in certain national regulatory frameworks, although to a lesser extent. Out of the 77 analyzed jurisdictions in which the use of the IFRS for Small and Medium Sized Entities is required or permitted or in which it served as the basis for the development of national standards for small and medium-sized entities , they have been modified in ten (13\%) of them (IFRS Foundation, 2014).

\section{UNEQUAL EFFICACY OF INCENTIVE MECHANISMS}

A strict application of the IFRS by companies around the world, and thus an increase in the global comparability of financial statements, cannot be 
achieved without effective incentive mechanisms, i.e. the systems encouraging their use, whose construction is under the exclusive auspices of national regulators. These are the mechanisms that include an obligation to audit companies' financial statements, the supervision of auditors by relevant authorities, and the sanctioning of any violation of laws and standards. Based on this, an unequal efficiency of incentive mechanisms could be an important source of differences in the practical application of the IFRS globally, and could also cause an uneven quality of financial reporting in different countries, which is maybe more dangerous. Moderate or inefficient incentive mechanisms allow companies to deviate from the provisions of the IFRS with impunity, making their financial statements incomparable with the statements of the companies from the countries in which the IFRS are strictly applied.

In this respect, the results of one empirical study, based on Egyptian companies' disclosures after transition to the national standards based on the IFRS, could be interesting. The research has shown that the companies were less willing to comply with the provisions of the new standards which were relatively unknown to them (Abd-Elsalam \& Weetman, 2003, 6384). These results confirm the importance of effective incentive mechanisms, which should ensure strict compliance with all the provisions of the IFRS.

Another study, focusing on the quality of information on the impairment of assets in the financial statements of European companies for 2010 and 2011, reveals that the degree of compliance with the provisions of the IFRS regarding the disclosure of impairment varies from one country to another, indicating an uneven application of the IFRS. The same research finds that high-quality reporting on the impairment of assets is characteristic of companies operating in a more solid institutional and regulatory environment, as is the case with companies in the UK and Ireland, while, in contrast, information on impairment provided by companies in countries with weaker regulatory control are of a lower quality. Additionally, companies in countries with strong incentive systems show a greater degree of timeliness in the recognition of impairment losses on assets than companies in countries with weaker incentive systems (Amiraslani, Iatridis \& Pope, 2013, 2).

\section{OVERCOMING DIFFERENCES IN PRACTICAL APPLICATION OF IFRS}

In the opinion of many, the different manners of applying the IFRS throughout the world represent „a significant challenge to the adoption of the IFRS as a truly global reporting model" (Securities and Exchange Commission, 2010, 10). Differences in the economic, legal and cultural environment are highlighted as the key obstacles to the consistent application of the IFRS. The insufficient knowledge of the IFRS and the inadequate level of the understanding of their potentials in certain countries as well as the widespread resistance to changes are important obstacles as well.

A situation when a multitude of the national versions of the IFRS exist could be even more dangerous than a situation when each country follows its own standards. When investors (and other users of financial statements) know that each country follows its own standards, as was the case in the past, they adapt their behavior in terms of studying foreign accounting systems, requesting a higher return rate on the basis of a higher expected risk or the cancellation of foreign investment. However, if all countries identify themselves as the followers of the IASB's standards, while each follows its own version of the IFRS, applying various procedures of auditing and the supervision of the implementation of such standards, investors can be misled regarding the comparability of the financial statements of companies from different parts of the world and, therefore, make wrong decisions. They may conclude that the financial statements of companies from different countries are comparable, although they are not comparable indeed, and may abandon their attempt to transform the statements to a comparable basis.

Reacting to the modifications of the IFRS in their incorporation into national regulatory frameworks, the International Organization of Securities Commissions (IOSCO), in its document published in 
2008, recommends that companies should provide clear and precise information about the standards used as the basis for the preparation of financial statements in order to facilitate their understanding by investors. However, the IOSCO recommendations cannot be considered as a long-term solution. The only correct long-term solution is the incorporation of the IASB's standards into national regulatory frameworks without any modification (Willemain, 2008, 1).

The IFRS Foundation has also recognized the dangers of the inconsistent application of the IFRS. In a document from 2012, which outlines its own strategy for the ten-year period, the IFRS Foundation emphasizes that countries opting for the application of the IFRS should avoid "creating national or regional variants of IFRS" (IFRS Foundation, 2012, 12), and that any incomplete application of the IFRS should be clearly indicated, which is similar to the recommendation of IOSCO. According to the IFRS Foundation, the IASB's contribution to increasing consistency in the application of the IFRS should consist of a publication of clear, understandable and applicable standards, providing guidelines for implementation as well as illustrative examples for understanding and the consistent implementation of the standards if necessary, and cooperation with national regulators and other stakeholders in order to identify the areas in which differences in the practical application of the IFRS between countries are present, and to improve the standards or the interpretations addressing these areas (IFRS Foundation, 2012, 5-6).

On the other hand, all stakeholders (preparers, auditors and analysts of financial statements, national regulators and others) should actively be involved in the process of creating new or revising the existing standards, through their comments on the IASB's proposals, and, if necessary, should require the IASB to clarify the standards. This would prevent differences in the interpretation of standards (Ernst \& Young, 2012, 8).

An important role the IASB has in making efforts to overcome differences in the practical application of the IFRS, and in particular differences of judgments caused by cultural factors, should be that of the conceptual framework for the IFRS, which, in fact, is "the IASB's statement about its own accounting culture" (Whittington, 2008, 497). To achieve true accounting convergence, it is necessary that the conceptual framework, which so far has primarily been aimed at ensuring the consistency of the standards and providing guidelines for situations not covered by the standards, should gain a new role of the promotion of the fundamental basis of financial reporting in a manner that overcomes the existing cultural differences between countries. The process of the conceptual framework reform, which is well under way and whose essence reflects in the review and modification of that fundamental basis, is a good opportunity to move the framework closer to interested parties around the world through their involvement in the reform process and by respecting their needs and interests. The reform of the conceptual framework, as one of the most important segments of the project of convergence between IFRS and U.S. Generally Accepted Accounting Principles (GAAP), should provide an opportunity for those who did not participate in the creation of the previous version of the framework (such as many EU countries) to express their views. Therefore, in order to achieve greater uniformity in financial reporting practices at a global level, the formal acceptance of the IFRS by national regulators should be followed by achieving as great a degree of a global consensus on the fundamental principles embedded in the framework as possible. The IFRS conceptual framework should promote the objectives, assumptions and fundamental principles of the IFRS worldwide, thus helping to better understand their philosophy and harmonize judgments from country to country.

It is impossible to achieve a consistent quality of the audit of financial statements on the global scale as a prerequisite of the consistent application of the IFRS without a single global set of auditing standards, which are being under construction. The International Standards on Auditing (ISA) issued by the International Federation of Accountants (IFAC) stand for the basis of the process of the global convergence of the auditing standards in the same way that the IFRS are the basis of the global convergence of the financial reporting standards. In addition to the harmonization of the auditing standards between countries, it is very important to harmonize the standards of professional 
ethics which accountants and auditors adhere to, and it is necessary to build an effective and globally harmonized system of licensing auditors, control and disciplining, so that investors could have absolute confidence in financial statements prepared and audited in different countries (Willemain, 2008, 2). Finally, there should be high-quality and consistent systems for educating accountants.

It is clear that a ultimate success in increasing the consistency of the IFRS application primarily depends on national financial reporting regulators, i.e. their willingness to consistently (without modification) incorporate the IFRS into their national regulatory frameworks and ensure the strict implementation of the same. National regulators also need to refrain from publishing their own IFRS interpretations and guidelines. Instead, in the case of any doubt or disputed issues, they should consult the IASB.

The reform of the worldwide regulatory environments, as a prerequisite of the ultimate success of the process of the global convergence of the financial reporting standards, is a long-term and challenging process (PricewaterhouseCoopers, 2007b, 4). Financial reporting regulators around the world need to work together in order to prevent occurrences of significant differences in regulatory environments.

The problem of national variations in the IFRS application could partially at least be overcome through the global supervision of the IFRS application. Thanks to global supervision, users of financial statements would be able to learn whether companies from a country declaring itself to be a follower of the IFRS truly apply all their provisions or not. Under conditions of global supervision, countries themselves would be interested in a consistent and timely adoption and strict implementation of the IFRS because putting a country on the list of those that do not strictly follow the IFRS would make it harder for their companies to attract foreign capital and would also have a negative impact on its international image. In recent years, the IASB has undertaken activities in this field by publishing jurisdiction profiles, in which, among other things, it specifies the areas where the national versions of the IFRS differ from the original version and explains the procedures of the national regulatory framework harmonization with the changes in the IFRS, including the translation of the IFRS.

\section{CONCLUSION}

The adoption of the IFRS by many countries in the world globally contributed to the harmonization of accounting practices. However, the research conducted in this paper has shown that a single global accounting practice is still far from reality, i.e. the characteristics of the IFRS themselves, the procedure of their incorporation into national regulatory frameworks and the weaknesses of national incentive mechanisms create a room for diversity (variations) in the application of the IFRS, thus confirming the main hypothesis of the study. Today, as a result of weaknesses and inconsistencies in the procedures of the incorporation of the IFRS into national regulatory frameworks, instead of a single version of the IFRS, there are a significant number of their nationally colored versions worldwide.

The key contribution of the paper reflects in identifying the causes of variations in the application of the IFRS, using the three-layer model based on dividing the causes to those related to the characteristics of the IFRS themselves, those related to the process of the incorporation of the IFRS into national regulatory frameworks, and those related to the implementation of the adopted IFRS (in the original or a modified form) at the national level. The contribution is also visible in pointing out the main activities to be undertaken in order to overcome the above-mentioned variations and the key actors to implement them the IASB and national regulators. In addition to this, the paper highlights the need for the globalization of the financial reporting standards to be followed by the globalization of the auditing standards and the procedures for the supervision of auditors by the authorized government bodies as well as the need for the education and training of accounting professionals due to the fact that the lack of an adequate effort in any of these areas can significantly counteract the efforts made in establishing the global financial reporting standards. The idea of the establishment of the global 
supervision of the application of the IFRS is also discussed.

The analysis of the activities in the updating of the financial reporting regulatory framework in the Republic of Serbia in accordance with the development of the IFRS, together with the general remarks on the ways how to overcome the variations in the application of the IFRS, suggests opportunities for improving the implementation of the IFRS in RS in the future. The Serbian financial reporting regulators should take care of the up-to-date translation of all the relevant IASB documents, with a continuous review and improvement of the translation quality, and should continuously strengthen mechanisms for disciplining auditors. Also, the national regulators should strive to refrain from adopting the regulations that would modify the provisions of the IFRS, wherein any modifications should only be made in a case of an extreme necessity. The accounting profession should work on the continuous improvement of training programs for accountants, with an emphasis on the proper understanding of the conceptual foundation of the financial reporting based on the IFRS. To the extent possible, regulators and the accounting profession should actively be involved in the development of the IFRS, primarily by their being allowed to make comments on drafts of the standards and interpretations and, should there be any dilemmas regarding the provisions of the already adopted IFRS, by their addressing the IASB.

The research in this paper is mainly focused on the estimation of the room for national variations in the application of the IFRS, which is also the major limitation of the paper. Therefore, the actual variation in the financial statements of companies from different countries declaring themselves to be the followers of the IFRS could be the subject of future research in this area. Taking into consideration the fact that special attention in the paper is paid to the incorporation of the IFRS into Serbia's regulatory framework, the comparability of the financial statements of the Serbian companies with the financial statements of companies from the other countries that have adopted the IFRS and the problems that RS accountants face in applying the IFRS are also the potential subjects of future research.

\section{REFERENCES}

Abd-Elsalam, O. H., \& Weetman, P. (2003). Introducing International Accounting Standards to an emerging capital market: relative familiarity and language effect in Egypt. Journal of International Accounting, Auditing and Taxation, 12(1), 63-84. doi: 10.1016/S1061-9518(03)00002-8.

Alali, F., \& Cao, L. (2010). International financial reporting standards - credible and reliable? An overview. Advances in Accounting, incorporating Advances in International Accounting, 26(1), 79-86. doi: 10.1016/j.adiac.2010.02.001.

Alfredson, K., Leo, K., Picker, R., Pacter, P., Radford, J., \& Wise, W. (2007). Applying International Financial Reporting Standards. Milton, Australia: John Wiley \& Sons Australia, Ltd.

Amiraslani, H., Iatridis, G. E., \& Pope, P. F. (2013). Accounting for asset impairment: a test for IFRS compliance across Europe. London, UK: Centre for Financial Analysis and Reporting Research, Cass Business School.

Armstrong, C. S., Barth, M. E., Jagolinzer, A. D., \& Riedl, E. J. (2010). Market Reaction to the Adoption of IFRS in Europe. The Accounting Review, 85(1), 31-61. doi: 10.2308/ accr.2010.85.1.31.

Bogicevic, J. (2013). Accounting implications of foreign currency transactions translation and hedging. Economic Horizons, 15(2), 137-151. doi:10.5937/ekonhor1302133B.

Cabrera, L. (2008). Widespread Acceptance of IFRS Continues: Is It Time for U.S. Companies to Prepare for the Transition? The CPA Journal, 78(3), 36-37.

Deloitte (2008). 2008 IFRS Survey: Where Are We Today? Deloitte Development LLC.

Deloitte Global Services Limited. (2014). IAS 27 - Separate Financial Statements. Retrieved October 13, 2014, from http:// www.iasplus.com/en/standards/ias/ias27-2011\#aug2014.

Doupnik, T., \& Perera, H. (2007). International Accounting. International Edition. New York, USA: McGraw-Hill.

Doupnik, T., \& Richter, M. (2004). The Impact of Culture on the Interpretation of "In Context" Verbal Probability Expressions. Journal of International Accounting Research, 3(1), $1-20$.

Epstein, B. J. (2009). The Economic Effects of IFRS Adoption. The CPA Journal, 79(3), 26-31.

Ernst \& Young (2012). Consistency in IFRS - no borders, one language: dream or reality? IFRS Outlook. UK: EYGM Limited. 
IFRS Foundation (2012). IFRSs as the Global Standards: Setting a Strategy for the Foundation's Second Decade. London, UK: IFRS Fondation.

IFRS Foundation (2014). Jurisdiction Profiles. Retrieved June 3, 2014, from http://www.ifrs.org/Use-around-the-world/ Pages/Jurisdiction-profiles.aspx.

KPMG \& von Keitz, I. (2006). The Application of IFRS: Choices in Practice. UK: KMPG IFRG Limited.

Kvaal, E., \& Nobes, C. (2010). International differences in IFRS policy choice: a research note. Accounting and Business Research, 40(2), 173-187.

McGee, R. W. (2006). Adopting and Implementing International Financial Reporting Standards in Transition Economies. In G. N. Gregoriou, \& Gaber M. (Eds.), International Accounting: Standards, Regulations, and Financial Reporting (pp. 199-223). Oxford, UK: Elsevier.

Nobes, C. (2013). The continued survival of international differences under IFRS. Accounting and Business Research, 43(2), 83-111. doi: 10.1080/00014788.2013.770644.

Nobes, C., \& Parker, R. (2010). Comparative International Accounting. Harlow, UK: Pearson Education Limited.

Pacter, P. (2013). What Have IASB and FASB Convergence Efforts Achieved? Journal of Accountancy, 215(2), 50-59.

Pacter, P. (2014). Global Accounting Standards - From Vision to Reality: Assessing the State of IFRS Adoption, Jurisdiction by Jurisdiction. The CPA Journal, 84(1), 6-10.

PricewaterhouseCoopers (2007a). International Financial Reporting Standards: The right move for US business. 10 Minutes on IFRS. Delaware, USA: PricewaterhouseCoopers LLP.
PricewaterhouseCoopers (2007b). ViewPoint: Convergence of IFRS and US GAAP. London, UK: PricewaterhouseCoopers.

PricewaterhouseCoopers (2010). IFRS adoption by country. Delaware, USA: PricewaterhouseCoopers LLP.

Saudagaran, S. M. (2009). International Accounting: A User Perspective. Chicago, USA: CCH.

Securities and Exchange Commission (2010). Commission Statement in Support of Convergence and Global Accounting Standards. Release Nos. 33-9109; 34-61578. Washington, USA: U.S. Securities and Exchange Commission.

Stevenson, K. M. (2008). The IASB: Some Personal Reflections. In J. M. Godfrey, \& Chalmers, K. (Eds.), Globalisation of Accounting Standards (pp. 34-45). Cheltenham, UK: Edward Edgar.

Tokar, M. (2005). Convergence and the Implementation of a Single Set of Global Standards: The Real-life Challenge. Accounting in Europe, 2, 48-68.

Whittington, G. (2008). Harmonisation or discord? The critical role of the IASB conceptual framework review. Journal of Accounting and Public Policy, 27(6), 495-502. doi: 10.1016/j. jaccpubpol.2008.09.006.

Willemain, J. (2008). Corporate reporting: Trends and tensions in convergence. Deloitte.

Zeff, S. A. (2007). Some obstacles to global financial reporting comparability and convergence at high level of quality. The British Accounting Review, 39(4), 290-302. doi: 10.1016/j. bar.2007.08.001.

\author{
Received on $22^{\text {nd }}$ August 2014, \\ after revision, \\ accepted for publication on $15^{\text {th }}$ December 2014. \\ Published online on $22^{\text {nd }}$ December 2014
}

Vladimir Obradovic is an Assistant Professor at the University of Kragujevac- the Faculty of Economics, where he has obtained his doctor's degree. He teaches the following courses: Financial Reporting, Special-purpose Financial Statements, and International Financial Reporting in the Specific Scientific Field of Accounting, Auditing and Business Finance. His scientific interests are primarily related to the international aspects and standards of financial reporting. 


\title{
NEKONZISTENTNA PRIMENA MEĐUNARODNIH STANDARDA FINANSIJSKOG IZVEŠTAVANJA
}

\author{
Vladimir Obradović* \\ Ekonomski fakultet Univerziteta u Kragujevcu
}

\begin{abstract}
Prerastanje Međunarodnih standarda finansijskog izveštavanja (IFRS) u jedinstveni globalni jezik finansijskog izveštavanja uveliko traje i prati problem njihove nekonzistentne primene od zemlje do zemlje, sa negativnim posledicama po globalnu uporedivost finansijskih izveštaja. Polazeći od toga, osnovni cilj istraživanja u ovom radu jeste da se sagledaju uzročnici razlika u praksi finansijskog izveštavanja onih zemalja koje se deklarišu kao sledbenice IFRS, i da se identifikuju načini da se prevaziđu te razlike. Primenom kvalitativne metodologije istraživanja utvrđeno je da fleksibilnost odredaba IFRS, koja je $\mathrm{u}$ mnogim slučajevima neizbežna, modifikacije prilikom njihove ugradnje $\mathrm{u}$ nacionalne regulatorne okvire, i raznolikost i nejednaka efikasnost nacionalnih mehanizama za njihovo nametanje i superviziju primene, predstavljaju glavne uzročnike nekonzistentnosti računovodstvenih praksi. Da bi se smanjila nekonzistentnost, potrebno je da se regulatori finansijskog izveštavanja više angažuju i bolje međusobno koordiniraju, ali i da Međunarodni odbor za računovodstvene standarde uloži dodatne napore, koji, pre svega, treba da budu usmereni na globalno promovisanje fundamentalnih osnova IFRS.
\end{abstract}

Ključne reči: finansijsko izveštavanje, Međunarodni standardi finansijskog izveštavanja (IFRS), Međunarodni komitet za računovodstvene standarde (IASB), nekonzistentna primena

\section{UVOD}

Pod uticajem globalizacije biznisa, a posebno tržišta kapitala, pitanje globalizacije standarda finansijskog izveštavanja dobilo je izuzetan značaj. Imajući u vidu neosporan stav da "razlike u računovodstvenim praksama predstavljaju barijeru za kretanje kapitala" (Saudagaran, 2009, 2.34), jasno je zašto jedinstveni kvalitetni globalni standardi finansijskog izveštavanja,

\footnotetext{
* Korespondencija: V. Obradović, Ekonomski fakultet Univerziteta u Kragujevcu, Đ. Pucara 3, 34000 Kragujevac, Srbija; e-mail: vobradovic@kg.ac.rs
}

koji bi se, na konzistentan način, primenjivali u svim zemljama, predstavljaju nešto čemu se „učesnici na globalnim tržištima kapitala već odavno nadaju“ (Cabrera, 2008, 36). Poslednjih godina, potreba za takvim standardima postala je naročito izražena, jer bi oni, svakako, omogućili da investitori, kreditori i drugi korisnici finansijskih izveštaja uporede, lakše i tačnije, finansijski položaj i uspešnost kompanija iz različitih zemalja.

Međunarodni standardi finansijskog izveštavanja (International Financial Reporting Standards - IFRS), koje donosi Međunarodni odbor za računovodstvene 
standarde (International Accounting Standards Board - IASB), danas predstavljaju najvažnije i najrasprostranjenije standarde finansijskog izveštavanja u svetskim razmerama, a isti imaju veliki potencijal da, na globalnom planu, postanu univerzalni. Pretvaranje IFRS $\mathrm{u}$ jedinstvene globalne standarde uveliko teče, a to potvrđuje i činjenica da broj zemalja koje ih slede neprestano raste, pri čemu mnoge zemlje koje još uvek imaju sopstvene standarde (poput SAD), nameravaju, u bližoj ili daljoj budućnosti, da ih usvoje. Širom sveta, IFRS se doživljavaju kao standardi dobrog kvaliteta (Epstein, 2009, 27), odnosno, kao „zadovoljavajuća globalna platforma, sa mogućnošću daljih poboljšanja" (PricewaterhouseCoopers, 2007a, 3), a dodatno poverenje $u$ njih uliva činjenica da se razvijaju uz uvažavanje stavova iz različitih delova sveta. IFRS nude značajne mogućnosti da se unaprede transparentnost i uporedivost finansijskih izveštaja na globalnom planu, dajući, na taj način, pozitivan efekat na razvoj i integraciju tržišta kapitala i na globalni ekonomski rast i razvoj uopšte. IASB, njihov donosilac, uspeo je da stekne status najuglednije svetske institucije koja donosi standarde finansijskog izveštavanja.

Međutim, kao privatno telo, IASB nema sposobnost da direktno nametne svoje standarde kompanijama, jer nema autoritet ni nad jednim revizorom, sastavljačem finansijskih izveštaja, niti nad regulatorom finansijskog izveštavanja (Stevenson, 2008, 34). U tom pogledu, njegova pozicija je drugačija od pozicije nacionalnih donosilaca standarda, koji funkcionišu u okviru nacionalnog regulatornog okvira i imaju jasno definisan autoritet. IASB-u, stoga, ne preostaje ništa drugo nego da razvija standarde kao javno dobro i da ih stavi na raspolaganje svim zemljama, ili kompanijama, koje žele da ih usvoje i primenjuju, ujedno podstičući nacionalna regulatorna tela da prihvate IFRS, $u$ skladu sa svojim mogućnostima i uticajem.

Pored toga, pošto nema direktan autoritet nad sastavljačima i revizorima finansijskih izveštaja, niti nad nacionalnim regulatorima finansijskog izveštavanja, IASB ne može da osigura konzistentnu primenu IFRS u svim zemljama koje se deklarišu kao njihove sledbenice. Upravo je problem nekonzistentne primene IFRS širom sveta poslednjih godina postao veoma izražen. Za razliku od ranijih decenija, u kojima je centralno pitanje bilo kako da se prevaziđu razlike između nacionalnih standarda, danas do izražaja sve više dolazi problem nekonzistentne primene istih standarda - IFRS.

Naime, kulturološki i drugi faktori okruženja mogu rezultirati različitim tumačenjima istih standarda i različitim nivoima njihovog poštovanja između zemalja, sa negativnim posledicama po uporedivost finansijskih izveštaja (Doupnik \& Perera, 2007, 103). Usvajanje IFRS u nekoj zemlji je jedna stvar, dok je njihova implementacija nešto drugo. Činjenica da je država usvojila nove računovodstvene principe i pravila ne garantuje njihovu brzu, efikasnu i potpunu primenu, jer je "možda potrebno promeniti stare mentalitete i načine rada, za šta je možda potrebna jedna generacija" (McGee, 2006, 202). Imajući to u vidu, konstatacija da „približavanje računovodstvenih standarda može da bude lakše od prevazilaženja kulturoloških razlika i perspektiva koje opredeljuju način na koji se IFRS tumače i primenjuju" (Deloitte, 2008 , 4) čini se ispravnom. Bez konzistentne primene IFRS ne može biti reči o postojanju jedinstvenog globalnog jezika finansijskog izveštavanja. Globalni standardi koji se primenjuju na nekonzistentan način, globalni su samo po nazivu (Ernst \& Young, 2012, 1).

Predmet istraživanja u ovom radu je raznolikost praksi finansijskog izveštavanja zemalja koje se deklarišu kao sledbenice IFRS, a osnovni cilj istraživanja jeste da se sagledaju glavni uzročnici i načini prevazilaženja te raznolikosti. U istraživačkom procesu biće testirana sledeća hipoteza: Karakteristike samih IFRS, procedure njihove ugradnje $\mathrm{u}$ nacionalne regulatorne okvire i slabosti nacionalnih podsticajnih mehanizama stvaraju prostor za ispoljavanje raznolikosti u primeni IFRS širom sveta.

Definisana hipoteza biće testirana primenom kvalitativne metodologije istraživanja zasnovane na deskriptivnoj analizi. Polazeći od relevantne literature koja sadrži teorijska razmatranja, i od analize konkretnih slučajeva, izvešće se opšti zaključci o razmatranom problemu. Od posebnog značaja biće metoda indukcije, kojom će se, polazeći od odredaba pojedinačnih standarda, izvući opšti zaključak o karakteristikama IFRS, a, s druge strane, preko slučajeva pojedinih zemalja zaključiće se o 
nedostacima mehanizama za pretvaranje IFRS $\mathrm{u}$ nacionalne standarde, kao i mehanizama koji treba da obezbede njihovu doslednu primenu. U radu će se koristiti i metoda komparacije koja će se zasnivati na upoređivanju odlika regulatornih režima i praksi finansijskog izveštavanja različitih zemalja.

Naredna tri segmenta rada posvećena su glavnim uzročnicima varijacija u praksama finansijskog izveštavanja onih zemalja koje slede IFRS. U prvom segmentu, razmatra se prostor za varijacije praksi koje, svojom fleksibilnošću, ostavljaju sami IFRS, u drugom, uzročnici nastanka nacionalnih verzija IFRS, a u trećem, slabosti nacionalnih podsticajnih mehanizama. U poslednjem, četvrtom, segmentu rada, ukazuje se na moguće načine za smanjivanje varijacija u primeni IFRS.

\section{FLEKSIBILNOST IFRS}

IFRS su, po svom karakteru, fleksibilni i, kao takvi, ostavljaju značajan prostor za izbor računovodstvenih praksi. Među faktore nekonzistentne primene IFRS u praksi, a koji su povezani sa karakteristikama samih IFRS, ubrajaju se (Nobes, 2013, 91-93):

- praznine u standardima,

- otvorene opcije u standardima,

- prikrivene opcije u standardima i neprecizni kriterijumi za priznavanje elemenata (pozicija) finansijskih izveštaja i

- potreba za prosuđivanjem prilikom merenja pozicija finansijskih izveštaja.

Iako IASB neprestano usavršava postojeće i donosi nove standarde $u$ skladu sa promenama poslovne prakse, izvesne praznine $\mathrm{u}$ standardima, $\mathrm{u}$ smislu nedostatka rešenja za neke specifične računovodstvene probleme, praktično je nemoguće izbeći. Toga je svestan i sam IASB koji u svom standardu posvećenom računovodstvenim politikama, promenama računovodstvenih procena i greškama (IAS 8) ističe da, $\mathrm{u}$ odsustvu standarda i tumačenja koji su posvećeni nekoj specifičnoj transakciji ili događaju, sastavljači finansijskih izveštaja treba da koriste svoje prosuđivanje, i da se oslanjaju na druge (nacionalne) standarde i tumačenja, koji su posvećeni sličnim problemima, kao i na IASB-ov konceptualni okvir.

Primer standarda koji ostavlja značajan prostor za širok spektar računovodstvenih praksi jeste IFRS 4 (Pacter, 2013, 55), koji se odnosi samo na opšta pitanja računovodstvenog tretmana ugovora o osiguranju, a ne nudi rešenja za sve probleme $u$ ovom području. Takođe, IFRS 6 ostavlja dosta prostora za različita rešenja računovodstvenih problema koji se javljaju u industriji nafte i gasa.

Suočavajući se sa prazninama u IFRS, sastavljači finansijskih izveštaja mogu odlučiti da nastave sa dugogodišnjom nacionalnom tradicijom, tj. tradicijom koja je uspostavljena pre usvajanja IFRS. U svakom slučaju, njima je ostavljen izvestan manevarski prostor koji može da ima negativne posledice na globalnu uporedivost finansijskih izveštaja. Nacionalni regulatori mogu da popune praznine $u$ IFRS kreiranjem standarda koji bi bili dopuna IFRS. Upravo je to učinio australijski donosilac standarda objavivši sopstvene standarde koji se bave nekim pitanjima ugovora o osiguranju, a koja nisu našla svoje mesto u IFRS, kao i drugim pitanjima koja su specifična za nacionalno okruženje (PricewaterhouseCoopers, 2010, 141). Mogućnost da nacionalni donosioci standarda širom sveta na različite načine reše probleme kojima se IASB nije bavio predstavlja dodatnu opasnost po globalnu uporedivost finansijskih izveštaja.

Jednu od bitnih karakteristika IFRS predstavljaju otvorene opcije, odnosno, različite mogućnosti za računovodstveni tretman istih računovodstvenih problema, što predstavlja značajan izvor razlika u praktičnoj primeni IFRS širom sveta. Kao karakteristični primeri situacija u kojima aktuelni IFRS nude opcije, izdvajaju se utvrđivanje vrednosti krajnjih zaliha i troškova disponiranih zaliha, gde postoji mogućnost izbora između FIFO metode i metode prosečnih troškova, kao i procenjivanje nekretnina, postrojenja, opreme i nekih nematerijalnih ulaganja nakon inicijalnog priznavanja, gde postoji mogućnost izbora između modela istorijskog troška i modela fer vrednosti. Kada se odlučuje o izboru jedne od ponuđenih metoda, ponovo dolazi do izražaja tradicija uspostavljena pre usvajanja IFRS. Na primer, s obzirom 
na ukorenjenu tradiciju, od britanskih kompanija se može očekivati primena FIFO metode obračuna zaliha, a od kompanija iz Nemačke primena metode prosečnih troškova (Nobes \& Parker, 2010, 160-161).

Generalno, broj opcija u standardima ima tendenciju opadanja (Alfredson et al, 2007, 33), zahvaljujući postepenom eliminisanju ranije ustanovljenih opcija. Ipak, razvoj IFRS donosi i nastanak novih opcija, a kao najsvežiji primer izdvaja se povećanje broja opcija za obračun ulaganja u zavisne, pridružene i zajednički kontrolisane entitete $u$ pojedinačnim izveštajima nakon izmena IAS 27, koje su se desile u avgustu 2014. godine. Naime, dvema već raspoloživim opcijama (obračun po nabavnom trošku i obračun po fer vrednosti) pridodata je treća - obračun po metodi učešća (Deloitte Global Services Limited, 2014).

Specifičnu kategoriju otvorenih opcija predstavljaju one koje nudi IFRS 1, koji se bavi problemom prelaska kompanija sa nacionalnih standarda na IFRS. Između ostalog, ovaj standard daje sastavljačima finansijskih izveštaja pravo da, prilikom sastavljanja prvih izveštaja na bazi IFRS, biraju između ponovne procene goodwill-a i preuzimanja njegovog zatečenog iznosa (tj. iznosa koji je nastao primenom prethodno važećih nacionalnih standarda), bez ponovne procene. Pošto se nacionalni standardi značajno razlikuju po pitanju računovodstvenog tretmana goodwill-a, i pošto prvi finansijski izveštaji na bazi IFRS čine polaznu osnovu za čitav niz narednih izveštaja, jasno je da opcije vezane za iznos goodwill-a u prvim izveštajima na bazi IFRS mogu u dugom roku da ostvare negativan uticaj na globalnu uporedivost finansijskih izveštaja.

Još jednu specifičnu kategoriju otvorenih opcija čine one koje proističu iz fleksibilnog datuma stupanja na snagu novih ili revidiranih standarda. Naime, prilikom objavljivanja svakog standarda, IASB utvrđuje datum njegovog stupanja na snagu, $i$ to $u$ vidu konstatacije da „,entitet treba da primenjuje standard za godišnje periode koji počinju 1. januara 20XX. godine, ili nakon tog datuma", pri čemu se kompanijama (entitetima) obično dopušta da sa primenom počnu i pre utvrđenog roka. Na primer, IASB je krajem 2006. godine IAS 14 zamenio sa IFRS 8. IFRS 8 je stupio na snagu 1. januara 2009. godine, ali je ostavljena mogućnost da počne ranije da se primenjuje. To praktično znači da su u
2007. i 2008. godini paralelno postojala dva različita standarda koji se bave istim računovodstvenim problemom (izveštavanjem po segmentima) - IAS 14 i IFRS 8, a kompanije su mogle da slede bilo koji od njih. Početkom 2007. godine IASB je izmenio standard posvećen troškovima pozajmljivanja (IAS 23), pri čemu je kao datum stupanja na snagu revidirane verzije standarda, takođe, označen 1. januar 2009. godine, uz mogućnost ranije primene, što znači da su do tog roka paralelno postojale dve verzije istog standarda. Fleksibilni rokovi za početak primene standarda $u$ osnovi imaju isti efekat kao i opcije $u$ samim standardima. Iako period paralelne egzistencije dvaju alternativnih standarda ili dveju verzija istog standarda (stare i nove) ne traje dugo (ne više od 2 do 3 godine), kontinuirano kreiranje i usavršavanje standarda donosi nove slučajeve paralelne egzistencije i, samim tim, stvara nove izvore razlika u praktičnoj primeni IFRS, ne samo na globalnom planu, već i na nivou jedne zemlje.

Osim otvorenih opcija, IFRS sadrže i brojne prikrivene opcije i neprecizno formulisane kriterijume za priznavanje elemenata finansijskih izveštaja (sredstava, obaveza, prihoda i rashoda), koji, dodatno, sastavljačima finansijskih izveštaja povećavaju prostor za izbor. Analizirajući IFRS koji su bili na snazi 2013. godine, C. Nobes $(2013,95)$ je identifikovao brojne primere situacija u kojima se sastavljači izveštaja suočavaju sa prikrivenim opcijama, ili nepreciznim kriterijumima za priznavanje. Neki od tih primera, ažurirani u skladu sa naknadnim izmenama IFRS, jesu:

- ocena značaja (materijalnosti) pojedinih stavki (IAS 8);

- klasifikacija lizinga na finansijski i operativni u zavisnosti od toga da li dolazi do prenošenja „suštinski svih rizika i koristi“ sa davaoca na korisnika lizinga, bez numeričkog kriterijuma (IAS 17);

- utvrđivanje funkcionalne valute (IAS 21);

- identifikovanje zavisnih entiteta na bazi „moći upravljanja" (IFRS 10), pridruženih entiteta na bazi „značajnog uticaja“ (IAS 28) i zajedničkih 
poduhvata na bazi „prava na neto imovinu aranžmana" (IAS 28);

- priznavanje pokrića, koje se vrši na bazi „verovatnoće odliva resursa" (IAS 37); i

- kapitalizovanje troškova razvoja (IAS 38).

Prethodne, ali i brojne druge nepomenute situacije predstavljaju neizbežnu posledicu prirode računovodstva, zbog koje se od standarda ne može očekivati odgovor na svako moguće pitanje. One proizilaze i iz IASB-ove sasvim ispravne orijentacije na standarde koji su zasnovani na principima čiju polaznu osnovu čini stav da se svrha standarda ogleda $\mathrm{u}$ definisanju prostora $\mathrm{u}$ kome računovođe donose odluke, odnosno, u kome vrše prosuđivanja koja ostaju sastavni deo računovodstva i finansijskog izveštavanja. Pošto IFRS ne sadrže jasne i precizne kriterijume za računovodstveni tretman brojnih transakcija i događaja, neophodno je da sastavljači finansijskih izveštaja, na bazi prosuđivanja, spoznaju njihovu ekonomsku suštinu i opredele se za adekvatan tretman. Način na koji sastavljači finansijskih izveštaja tumače ekonomsku suštinu transakcija i događaja, u značajnoj meri, zavisi od okruženja u kojem žive i rade, odnosno, od vrednosnih stavova društva kojem pripadaju. Na primer, jedno istraživanje je otkrilo da, usled razlika u kulturološkim vrednostima, nemačke računovođe $u$ poređenju sa američkim opreznije tumače reč "verovatno“, koja se često sreće u IFRS (Doupnik \& Richter, 2004, 1-20).

Računovodstvena prosuđivanja nisu vezana samo za priznavanje pozicija finansijskih izveštaja, već dolaze do izražaja i kada se utvrđuju njihove vrednosti na bazi IFRS. Naime, u svim situacijama u kojima ne postoje egzaktni i objektivni kriterijumi za merenje, razborita procena računovođa predstavlja jedino rešenje, pri čemu računovođe iz različitih zemalja ispoljavaju različite sklonosti, pod uticajem kulture, tradicije i poreskih propisa.

Otpisivanje nekretnina, postrojenja, opreme jeste područje u kojem potreba za prosuđivanjem dolazi do punog izražaja, i to kada se određuje korisni vek trajanja, procenjuje rezidualna vrednost (likvidacioni ostatak) i biraju metode otpisivanja. Analizirajući prakse otpisivanja u evropskim zemljama, C. Nobes i R. Parker $(2010,163)$ ističu da britanske kompanije, po tradiciji, teže jednostavnijim režimima otpisivanja koji podrazumevaju primenu pravolinijske metode, rezidualni ostatak jednak nuli i vek trajanja od 10 godina, dok kompanije iz nekih zemalja kontinentalne Evrope, pod uticajem poreskih propisa, tradicionalno koriste degresivnu metodu otpisa, uz težnju ka što kraćem korisnom veku trajanja. Utvrđivanje fer vrednosti sredstava i obaveza, takođe, uključuje prosuđivanje i smatra se veoma osetliivim područjem finansijskog izveštavanja. Neizbežno se prosuđuju i neto prodajna vrednost zaliha, iznos obezvređenja nekretnina, postrojenja i opreme, kao i vrednost pokrića.

Procenjeni iznosi u finansijskim izveštajima kompanija iz jedne zemlje zavise i od toga da li se u dotičnoj zemlji daje prednost opreznosti ili optimizmu. Na primer, ako preovlađuje sklonost ka opreznosti, veća je verovatnoća da će kompanije odabrati otpisivanje po degresivnoj metodi, uz kraći vek trajanja i niži procenjeni rezidualni ostatak, kao i da će pokrića proceniti u višim iznosima.

Na bazi prethodnih izlaganja može se konstatovati da, s jedne strane, IFRS donose napredak na planu povećanja međunarodne uporedivosti i konzistentnosti finansijskih izveštaja kompanija, a, s druge strane, istovremeno omogućavaju da finansijsko izveštavanje i dalje ostane nacionalno obojeno, tj. da i dalje nosi pečat prethodno važećih nacionalnih standarda. O tome jasno govore rezultati jednog empirijskog istraživanja koje je u centar pažnje stavilo 16 računovodstvenih pitanja kod kojih IFRS dopuštaju varijacije i u kojima su postojale međunarodne razlike pre usvajanja IFRS od strane zemalja iz kojih posmatrane kompanije potiču. Istraživanje je pokazalo da su razlike ostale i nakon što se prešlo na IFRS, tj. da su kompanije zadržale nacionalne tradicije (Kvaal \& Nobes, 2010). Drugo istraživanje, koje je u centar pažnje stavilo 26 otvorenih (eksplicitnih) opcija koje nude IFRS, otkrilo je da pripadnost određenoj zemlji i njeni prethodni standardi finansijskog izveštavanja ostvaruju najveći uticaj na računovodstvene izbore kompanija (KPMG \& von Keitz, 2006). 


\section{NACIONALNE VERZIJE IFRS}

Pored karakteristika samih IFRS, tj. brojnih otvorenih pitanja čiji konačan odgovor treba da daju sastavljači finansijskih izveštaja, značajne razlike $\mathrm{u}$ računovodstvenim praksama kompanija koje slede IFRS nastaju i prilikom ugradnje IFRS u regulatorne okvire finansijskog izveštavanja zemalja. Nedostatak direktnog autoriteta IASB-a doveo je do toga da se u nekim zemljama, umesto originalne verzije IFRS koju objavljuje IASB, primenjuje njihova modifikovana verzija (Alali \& Cao, 2010, 79). Drugim rečima, pored originalne IASB-ove verzije, postoje i nacionalne verzije IFRS, koje, u manjoj ili većoj meri, odstupaju od originalne.

Nakon razmatranja relevantne literature (IFRS Foundation, 2014; Nobes, 2013, 89-90; Nobes \& Parker, 2010, 158-159), može se konstatovati da se kao najznačajniji razlozi za nastanak nacionalnih verzija IFRS izdvajaju:

- modifikacije odredaba IFRS od strane nacionalnih regulatora;

- kašnjenje sa ugradnjom novih ili izmenjenih standarda ili odlaganje početka njihove primene; i

- greške u prevodu IFRS.

Mnoge zemlje prihvataju IFRS na indirektan način, tako što ih pretvaraju u sopstvene standarde, uz poštovanje manje ili više komplikovane procedure usvajanja koju sprovodi merodavno regulatorno telo, koje po svom karakteru može da bude nacionalno (kao što je, na primer, u Australiji), ili, pak, zajedničko za grupu zemalja (kao što je slučaj sa zemljama Evropske unije). Pri tome, IASB-ovi standardi mogu da budu ugrađeni u nacionalni regulatorni okvir bez ikakvih izmena, što se najčešće i događa, ali i da pretrpe odgovarajuće izmene ne bi li se prilagodili specifičnim okolnostima.

U nekim slučajevima modifikacije se ogledaju samo u eliminisanju pojedinih opcija za računovodstveni tretman. Na primer, prilikom ugradnje IFRS $u$ regulatorni okvir Brazila izbrisane su odredbe koje dopuštaju periodičnu revalorizaciju pozicija finansijskih izveštaja (IFRS Foundation, 2014). Brisanje pojedinih opcija dovodi do odstupanja nacionalnih standarda od IFRS, ali za kompanije koje dosledno poštuju nacionalne standarde ne može se reći da odstupaju od IFRS.

Znatno ozbiljniji problem po globalnu uporedivost finansijskih izveštaja nastaje ukoliko neka zemlja, ili grupa zemalja, suštinski izmeni odredbe IFRS, kao što je učinila Evropska unija (EU) sa odredbama IAS 39. Naime, IASB je 2003. i 2004. godine izmenio IAS 39 , što je izazvalo oštre reakcije u EU, a najznačajnije primedbe odnosile su se na: računovodstveni tretman finansijskih derivata i hedžinga, i proširenje upotrebe fer vrednosti u svrhe merenja finansijskih sredstava i obaveza u odnosu na dotadašnju verziju istog standarda (Armstrong et al, 2010, 34-35). Pomenute primedbe rezultirale su usvajanjem modifikovane verzije IAS 39 od strane Evropske komisije novembra 2004. godine, pri čemu se modifikacije ogledaju u eliminisanju spornih odredaba vezanih za računovodstvo hedžinga i upotrebu fer vrednosti. Ove modifikacije učinile su da verzija IFRS koju slede kompanije iz EU postane različita od originalne, IASB-ove verzije. Kasnije, upravo pod pritiskom EU, IASB je ponovo revidirao IAS 39 i ograničio upotrebu fer vrednosti samo na situacije u kojima se ona može pouzdano utvrditi. EU je usvojila izvršene izmene, čime je nestala jedna značajna razlika između originalne verzije IAS 39 i verzije istog standarda koja važi na nivou EU.

Iz prethodno izloženog proističe da je proces ugradnje IFRS $\mathrm{u}$ regulatorni okvir EU praktično kreirao nove standarde, standarde EU (Tokar, 2005, 49). Povoljna okolnost je to što razlike između originalne verzije IFRS i njihove verzije koju slede kompanije iz EU nemaju veliki praktičan značaj, s obzirom na to da utiču na finansijsko izveštavanje veoma malog broja kompanija (Pacter, 2014, 8).

Proces ugradnje svakog novog ili izmenjenog standarda i tumačenja u nacionalni regulatorni okvir odvija se na različite načine od zemlje do zemlje, i različito traje. Ukoliko neka zemlja ne usvoji standard ili tumačenje na vreme, tj. do dana koji je IASB označio kao dan njegovog stupanja na snagu, pojaviće se razlika između verzije IFRS koju dotična zemlja sledi i verzije koju slede zemlje koje su na vreme okončale proces usvajanja. 
Među zemljama koje su do sada neažurno prilagođavale sopstvenu regulativu finansijskog izveštavanja izmenama IFRS jeste i Republika Srbija (RS). Naime, prvi zvanični prevodi IFRS objavljeni su u decembru 2003. godine i obuhvatili su konceptualni okvir i sve Međunarodne računovodstvene standarde (IAS), ali ne i tumačenja. U januaru 2004. godine objavljen je prevod IFRS 1, nakon čega sledi pauza $\mathrm{u}$ objavljivanju prevoda od četiri godine, tokom koje je IASB objavio 6 novih standarda koji su u istom periodu stupili na snagu (IFRS 2-7), a, takođe, i revidirao značajan broj postojećih standarda (na primer, u decembru 2003. godine, IASB je izmenio IAS 2 ukinuvši mogućnost primene LIFO metode za obračun zaliha, pri čemu je revidirani standard stupio na snagu 1. januara 2005. godine). Pošto su izostale aktivnosti na planu objavljivanja zvaničnih prevoda novih i revidiranih standarda od strane merodavnih regulatornih tela, desilo se da je verzija IFRS koju su sledile kompanije iz RS bila značajno drugačija od njihove originalne verzije. $U$ februaru 2008. godine konačno su objavljeni novi prevodi IFRS, koji su zamenili prevode iz 2003. i 2004. godine. Uz prevode standarda, po prvi put, objavljeni su i prevodi tumačenja, ali ne i dopunski materijali vezani za standarde (osnove za zaključivanje, ilustrujući primeri, smernice, komentari i suprotna mišljenja), što se može smatrati nedostatkom, jer bi navedeni dodaci olakšali razumevanje standarda i njihovu implementaciju. U tom pogledu, prevodi iz 2008. godine predstavljaju korak unazad u odnosu na prevode iz 2003. godine, koji su uključivali i dopunske materijale (priloge). Naredna verzija prevoda IFRS objavljena je u oktobru 2010. godine, dok je poslednja verzija objavljena 2014. godine. Ako se uzme u obzir i činjenica da je IASBov standard posvećen malim i srednjim entitetima, donet 2009. godine, ugrađen u regulatorni okvir RS tek 2013. godine, čime je preduzećima koja potpadaju pod njegov delokrug (tj. preduzećima bez javne odgovornosti) bila uskraćena mogućnost korišćenja jednostavnije verzije IFRS $\mathrm{i}$ ostvarenja uštede $u$ troškovima sastavljanja finansijskih izveštaja, jasno je da se dosadašnje aktivnosti na planu ažuriranja regulatornog okvira finansijskog izveštavanja u RS u skladu sa promenama IFRS ne bi mogle oceniti kao zadovoljavajuće. Objavljivanje zvaničnih prevoda IFRS do sada je uglavnom kasnilo, tako da verzija IFRS koja se primenjuje u RS uglavnom nije odgovarala IASBovoj verziji. Tome treba dodati da je podzakonskim aktom iz 2009. godine kompanijama iz RS dopušteno da primene računovodstveni postupak koji nije konzistentan sa odredbama IAS 21 koje tangiraju transakcije u stranoj valuti (Bogicevic, 2013). Ova opcija bila je na snazi do septembra 2014. godine. Takođe, Narodna banka Srbije od finansijskih institucija zahteva da primenjuju računovodstvene postupke koji nisu sasvim podudarni sa zahtevima IFRS.

Ni blagovremeno usvajanje svih novih ili izmenjenih standarda ne garantuje automatski blagovremeni početak njihove primene, jer nacionalni regulator može da dopusti kompanijama (svim ili samo nekim) da početak primene odlože na određeno vreme. $\mathrm{Na}$ primer, u Tajvanu je odloženo primenjivanje šest standarda (IFRS Foundation, 2014).

Prevođenje IFRS sa engleskog jezika, na kome se objavljuje njihova originalna, zvanična verzija, na druge jezike sveta, neminovno podrazumeva rizik od promene njihovog smisla. Naime, potpunu ekvivalentnost prevoda bilo kog teksta sa njegovom originalnom verzijom nije lako ostvariti, pri čemu opasnost odstupanja od smisla originalnog teksta raste sa porastom broja korišćenih stručnih termina. IFRS obiluju stručnim terminima, za koje je često teško pronaći adekvatan prevod. Poseban problem predstavljaju odredbe IFRS koji sadrže nove koncepte, ili se bave problemima koji su nedovoljno poznati ili nepoznati u mnogim nacionalnim kulturama. Čak i najtačniji prevod takvih odredaba ne garantuje potpuno prenošenje njihove suštine i logike. Stoga, može se pojaviti situacija u kojoj se reči možda mogu razumeti, ali ne i koncepti (Zeff, 2007, 296).

O razmerama odstupanja prevoda od originalnih odredaba IFRS jasno govore naredna tri primera.

Prema originalnoj verziji IAS 41, bezuslovna subvencija države $u$ vezi sa biološkim sredstvom treba da bude priznata kao prihod u trenutku kada kompanija po tom osnovu stekne potraživanje, dok se, prema prevodu istog standarda na norveški jezik koji je publikovan 2006. godine, priznavanje prihoda vezuje za trenutak priliva novca po osnovu subvencije. 
U originalnoj verziji IAS 7, gotovinski ekvivalenti su definisani kao ulaganja "sa kratkim rokom dospeća, koji je, recimo, kraći od tri meseca", kojom je IASB pokušao da izbegne formulisanje krutog pravila. Međutim, u portugalskom prevodu reč "recimo“ je izostavljena, čime je fleksibilan princip pretvoren $\mathrm{u}$ čvrsto pravilo. Stoga je u Portugalu znatno teže odbraniti stav da neko ulaganje sa rokom dospeća neznatno dužim od tri meseca u suštini predstavlja gotovinski ekvivalent $u$ poređenju sa nekom drugom zemljom u kojoj je prevod korektan.

Prema originalnoj verziji IAS 19, diskontna stopa za obaveze po osnovu penzija utvrđuje se na bazi kamatne stope na korporativne obveznice, dok se prema nemačkom prevodu ona utvrđuje na bazi kamatne stope na industrijske obveznice, koje predstavljaju užu kategoriju od korporativnih obveznica (Nobes \& Parker, 2010, 159).

Analiza profila jurisdikcija (koje se uglavnom poklapaju sa nezavisnim državama), izrađenih između juna 2013. i septembra 2014. godine i objavljenih na sajtu IFRS Fondacije (entiteta zaduženog za upravljanje IASB-om, nadzor njegovog rada i njegovo finansiranje), otkriva da postoji značajan broj jurisdikcija u kojima su IFRS na neki način modifikovani. Od 127 analiziranih jurisdikcija $u$ kojima je primena IFRS obavezna ili dopuštena barem nekim kompanijama, u 53 jurisdikcije (42\%) primenjuje se njihova verzija različita od aktuelne IASB-ove verzije, usled modifikovanja odredaba IFRS, kašnjenja sa ugradnjom novih ili izmenjenih standarda, ili odlaganja početka primene nekih standarda ili tumačenja. U tri jurisdikcije modifikacije se odnose samo na eliminisanje opcija koje nude IFRS. Većina analiziranih jurisdikcija u kojima se primenjuje modifikovana verzija IFRS (28) pripada Evropskoj uniji. Modifikacije su izvršene i prilikom ugradnje IFRS za male i srednje entitete $\mathrm{u}$ određene nacionalne regulatorne okvire, mada $\mathrm{u}$ manjoj meri. Od 77 analiziranih jurisdikcija, u kojima je primena IFRS za male i srednje entitete obavezna ili dopuštena, ili u kojima je on poslužio kao osnova za razvoj domaćih standarda za male i srednje entitete, u $10(13 \%)$ izvršene su njegove modifikacije (IFRS Foundation, 2014).

\section{NEJEDNAKA EFIKASNOST PODSTICAJNIH MEHANIZAMA}

Striktnu primenu IFRS (od strane kompanija) širom sveta, a samim tim i povećanje globalne uporedivosti finansijskih izveštaja, nije moguće ostvariti bez efikasnih podsticajnih mehanizama, odnosno, sistema za podsticanje njihove primene, čija je izgradnja $u$ isključivoj nadležnosti nacionalnih regulatora. Reč je o mehanizmima koji uključuju obavezu revizije finansijskih izveštaja kompanija, superviziju rada revizora od strane nadležnih tela, i sankcije za svako kršenje zakona i standarda. Ako se pođe od toga, nejednaka efikasnost podsticajnih mehanizama može da bude značajan izvor razlika u praktičnoj primeni IFRS na globalnom planu, a, takođe, i uzrok nejednakog kvaliteta finansijskog izveštavanja između zemalja, što je možda i opasnije. Blagi ili neefikasni podsticajni mehanizmi omogućavaju kompanijama da nekažnjeno odstupe od odredaba IFRS, i tako njihovi finansijski izveštaji postaju neuporedivi sa izveštajima kompanija iz zemalja u kojima se IFRS striktno poštuju.

S tim u vezi, interesantni su rezultati jednog empirijskog istraživanja koje je bazirano na obelodanjivanjima egipatskih kompanija nakon što su prešle na nacionalne standarde koji su razvijeni na bazi IFRS. Istraživanje je pokazalo da su kompanije bile manje spremne da se povinuju odredbama novih standarda koje su im bile relativno nepoznate (AbdElsalam \& Weetman, 2003). Ovi rezultati potvrđuju značaj efikasnih podsticajnih mehanizama, koji treba da obezbede striktno poštovanje svih odredaba IFRS.

Drugo istraživanje, koje se fokusiralo na kvalitet informacija o obezvređenju sredstava u finansijskim izveštajima evropskih kompanija za 2010. i 2011. godinu, otkrilo je da stepen poštovanja odredaba IFRS, koje se tiču obelodanjivanja o obezvređenju, varira od zemlje do zemlje, što ukazuje na neujednačenost primene IFRS. Isto istraživanje je otkrilo da kvalitetno izveštavanje o obezvređenju sredstava karakteriše kompanije koje posluju u čvršćem regulatornom i institucionalnom ambijentu, kao što je slučaj sa kompanijama iz Velike Britanije i Irske, dok su, nasuprot tome, informacije o obezvređenju koje pružaju kompanije iz zemalja sa slabijom regulatornom kontrolom nižeg kvaliteta. Takođe, kompanije iz 
zemalja sa jakim podsticajnim sistemima pokazuju veći stepen blagovremenosti u priznavanju gubitaka po osnovu obezvređenja sredstava nego kompanije iz zemalja sa slabijim podsticajnim sistemima (Amiraslani, Iatridis \& Pope, 2013, 2).

\section{PREVAZILAŽENJE RAZLIKA U PRAKTIČNOJ PRIMENI IFRS}

Različiti načini primene IFRS širom sveta predstavljaju, po mišljenju mnogih, „značajan izazov za prihvatanje IFRS kao istinskog globalnog modela izveštavanja" (Securities and Exchange Commission, 2010, 10). Kao ključne prepreke za konzistentnu primenu IFRS ističu se razlike u ekonomskom, pravnom i kulturološkom okruženju. Tome treba dodati nedovoljan nivo poznavanja IFRS i nedovoljan stepen razumevanja njihovih potencijalnih koristi u pojedinim zemljama, ali i prisutan otpor promenama.

Situacija u kojoj postoji mnoštvo nacionalnih verzija IFRS može da bude čak i opasnija od situacije $u$ kojoj svaka zemlja sledi sopstvene standarde. Kada je investitorima (i drugim korisnicima finansijskih izveštaja) poznato da svaka zemlja sledi sopstvene standarde, kao što je bio slučaj u prošlosti, oni tome prilagođavaju svoje ponašanje tako što se upoznaju sa inostranim računovodstvenim sistemima, zahtevaju više stope prinosa po osnovu većeg očekivanog rizika ili odustaju od inostranih ulaganja. Međutim, ukoliko se sve zemlje deklarišu kao sledbenice IASB-ovih standarda, pri čemu svaka sledi sopstvenu verziju IFRS uz poštovanje različitih procedura revizije i supervizije primene standarda, investitori mogu biti dovedeni $u$ zabludu u pogledu uporedivosti finansijskih izveštaja kompanija iz različitih delova sveta i, samim tim, doneti pogrešne odluke. Oni mogu zaključiti da su finansijski izveštaji kompanija iz različitih zemalja uporedivi, iako zapravo nisu, i odustati od pokušaja da ih svedu na uporedivu osnovu.

Reagujući na modifikacije IFRS prilikom njihove ugradnje $u$ nacionalne regulatorne okvire, Međunarodna organizacija komisija za hartije od vrednosti (IOSCO) izdala je, u svom dokumentu iz
2008. godine, preporuku kompanijama da, u cilju lakšeg razumevanja finansijskih izveštaja od strane investitora, pruže jasne i precizne informacije $\mathrm{o}$ standardima koje koriste kao osnovu za njihovo sastavljanje. Ipak, preporuka IOSCO-a se ne može smatrati dugoročnim rešenjem. Jedino ispravno dugoročno rešenje jeste ugradnja IASB-ovih standarda $\mathrm{u}$ nacionalne regulatorne okvire bez ikakvih modifikacija (Willemain, 2008, 1).

Opasnosti koje donosi nekonzistentna primena IFRS spoznala je i IFRS Fondacija. U svom dokumentu iz 2012. godine kojim je definisala sopstvenu strategiju za desetogodišnji period, IFRS Fondacija je istakla da zemlje koje su se opredelile za primenu IFRS treba da „izbegavaju stvaranje nacionalnih ili regionalnih varijanti IFRS“ (IFRS Foundation, 2012, 12), a da svaka eventualna nepotpuna primena IFRS treba da bude jasno naznačena, što je slično preporuci IOSCO-a. Doprinos IASB-a povećanju konzistentnosti primene IFRS, prema IFRS Fondaciji, treba da se ogleda u (IFRS Foundation, 2012, 5-6):

- objavljivanju jasnih, razumljivih i primenljivih standarda;

- pružanju smernica za primenu i ilustrativnih primera, ukoliko je to potrebno da bi se razumeli i implementirali standardi na konzistentan način;

- saradnji sa nacionalnim regulatorima i ostalim interesentima, da bi se identifikovala područja u kojima se ispoljavaju razlike u praktičnoj primeni IFRS između zemalja i unapredili standardi ili tumačenja koji se odnose na ova područja.

S druge strane, svi interesenti (sastavljači, revizori i analitičari finansijskih izveštaja, nacionalni regulatori i ostali) treba da se aktivno uključe u proces donošenja novih ili revidiranja postojećih standarda, putem svojih komentara o predlozima IASB-a, kao i da, po potrebi, od IASB-a zahtevaju pojašnjenja standarda. Time će se preduprediti razlike $\mathrm{u}$ interpretaciji standarda (Ernst \& Young, 2012, 8).

Značajnu ulogu u naporima IASB-a da se prevaziđu razlike u praktičnoj primeni IFRS, a naročito razlika $\mathrm{u}$ prosuđivanjima prouzrokovanim kulturološkim 
faktorima, treba da ima konceptualni okvir IFRS, koji, zapravo, predstavlja „IASB-ov izveštaj o sopstvenoj računovodstvenoj kulturi" (Whittington, 2008, 497). Za ostvarenje istinske računovodstvene konvergencije, neophodno je da konceptualni okvir, koji je do sada bio prevashodno usmeren ka obezbeđenju konzistentnosti standarda i pružanju smernica za situacije koje nisu obuhvaćene standardima, dobije novu ulogu koja se ogleda $\mathrm{u}$ promovisanju fundamentalnih osnova finansijskog izveštavanja na način koji prevazilazi postojeće kulturološke razlike između zemalja. Proces reforme konceptualnog okvira, koji uveliko traje, i čija se suština ogleda u preispitivanju i modifikovanju tih fundamentalnih osnova, predstavlja dobru priliku da se sam okvir približi interesentima širom sveta, i to tako što bi se uključili u proces reforme i što bi se uvažile njihove potrebe i interesi. Reforma konceptualnog okvira, kao jedan od najznačajnijih segmenata projekta konvergencije IFRS i opšteprihvaćenih računovodstvenih principa (GAAP) SAD, treba da pruži mogućnost onima koji nisu učestvovali $u$ donošenju prethodne verzije okvira (kao što su mnoge zemlje EU) da iznesu svoj stav. Dakle, da bi se postigla što veća ujednačenost praksi finansijskog izveštavanja na globalnom planu, formalno prihvatanje IFRS od strane nacionalnih regulatora treba da bude praćeno postizanjem što većeg stepena globalne saglasnosti o fundamentalnim principima koji su u njih ugrađeni. Konceptualni okvir IFRS treba širom sveta da promoviše ciljeve, pretpostavke i fundamentalne principe IFRS, i time pomogne da se bolje razume njihova filozofija $\mathrm{i}$ da se ujednače prosuđivanja od zemlje do zemlje.

Konzistentan kvalitet revizije finansijskih izveštaja na globalnom planu, kao preduslov ujednačene primene IFRS, nemoguće je dostići bez jedinstvenih globalnih standarda revizije, čija je izgradnja u toku. Naime, Međunarodni standardi revizije (International Standards on Auditing - ISA), koje donosi Međunarodna federacija računovođa (IFAC), predstavljaju osnovu za proces globalne konvergencije standarda revizije, kao što IFRS predstavljaju osnovu za globalnu konvergenciju standarda finansijskog izveštavanja. Pored standarda revizije, važno je da standardi profesionalne etike, kojih se računovođe i revizori pridržavaju, budu ujednačeni između zemalja, a da bi investitori stekli puno poverenje $\mathrm{u}$ finansijske izveštaje sastavljene i revidirane u različitim zemljama, neophodno je izgraditi efikasne i na globalnom planu ujednačene sisteme licenciranja, kontrole i disciplinovanja revizora (Willemain, 2008, 2). Konačno, sistemi edukacije računovođa treba da budu kvalitetni i konzistentni.

Jasno je da krajnji uspeh na planu povećanja konzistentnosti primene IFRS prevashodno zavisi od nacionalnih regulatora finansijskog izveštavanja, odnosno, od njihove spremnosti da ih dosledno (bez modifikacija) ugrade u nacionalne regulatorne okvire i obezbede njihovu striktnu primenu. Nacionalni regulatori, takođe, treba da se uzdrže od objavljivanja sopstvenih tumačenja IFRS i smernica za njihovu primenu. Umesto toga, oni treba, u slučaju bilo kakvih nedoumica ili spornih pitanja, da se obrate IASB-u.

Reforma regulatornih okruženja širom sveta, kao neophodan preduslov potpunog uspeha procesa globalne konvergencije standarda finansijskog izveštavanja, predstavlja dugoročan i izazovan proces (PricewaterhouseCoopers, 2007b, 4). Regulatori finansijskog izveštavanja širom sveta moraju međusobno da sarađuju, kako bi se predupredila pojava značajnih razlika u regulatornim okruženjima.

Problem nacionalnih varijacija $\mathrm{u}$ primeni IFRS mogao bi, barem delimično, da se prevaziđe kroz globalnu superviziju primene IFRS. Zahvaljujući njoj, korisnici finansijskih izveštaja bi mogli da saznaju da li kompanije iz neke zemlje, koja se deklariše kao sledbenica IFRS, zaista poštuju sve njihove odredbe. Ako bi postojala globalna supervizija, zemlje bi bile zainteresovane za dosledno i ažurno usvajanje i striktnu primenu IFRS, jer kada bi jedna zemlja bila stavljena na listu onih koje ne slede striktno IFRS, njene kompanije bi se suočile sa teškoćama u privlačenju inostranog kapitala, a to bi, takođe, negativno uticalo na njen međunarodni imidž. Poslednjih godina IASB preduzima aktivnosti na tom planu tako što objavljuje profile jurisdikcija, u kojima se, između ostalog, navode područja u kojima se nacionalne verzije IFRS razlikuju od originalne verzije i objašnjavaju procedure usklađivanja nacionalnih regulatornih okvira sa izmenama IFRS, uključujući i prevođenje IFRS. 


\section{ZAKLJUČAK}

Prihvatanje IFRS od strane brojnih zemalja bez sumnje je doprinelo da se ujednače računovodstvene prakse na globalnom nivou. Ipak, istraživanja u ovom radu pokazuju da su jedinstvene globalne računovodstvene prakse i dalje daleko od realnosti, tj. da karakteristike samih IFRS, procedure njihove ugradnje $u$ nacionalne regulatorne okvire i slabosti nacionalnih podsticajnih mehanizama stvaraju prostor da se ispolje raznolikosti (varijacije) u primeni IFRS, čime je potvrđena hipoteza od koje se pošlo $u$ istraživanju. Slabosti i nekonzistentnosti procedura ugradnje IFRS $u$ nacionalne regulatorne okvire učinile su da danas, umesto jedinstvene verzije IFRS, u svetu figurira veći broj njihovih nacionalno obojenih verzija.

Ključni doprinos rada je u sagledavanju uzročnika varijacija $\mathrm{u}$ primeni IFRS putem troslojnog modela koji se zasniva na razdvajanju uzročnika povezanih sa karakteristikama samih IFRS, zatim, uzročnika povezanih sa procesom njihove ugradnje $u$ nacionalne regulatorne okvire, i uzročnika povezanih sa primenom usvojenih IFRS $(u$ originalnoj ili modifikovanoj formi) na nacionalnom nivou. Doprinos se ogleda i u ukazivanju na glavne aktivnosti koje treba preduzeti da bi se prevazišle pomenute varijacije, $i$ ukazivanju na ključne aktere koji treba da ih realizuju IASB i nacionalne regulatore. Predočena je i potreba da globalizacija standarda finansijskog izveštavanja bude praćena globalizacijom standarda revizije i procedura supervizije rada revizora od strane merodavnih državnih tela, kao i potreba za obrazovanjem i stručnim usavršavanjem računovodstvenih profesionalaca, s obzirom na to da izostanak adekvatnih napora na bilo kom od ovih polja može, u značajnoj meri, da poništi napore na planu izgradnje globalnih standarda finansijskog izveštavanja. Takođe, razmotrena je ideja o ustanovljenju globalne supervizije primene IFRS.

Analiza dosadašnjih aktivnosti na planu ažuriranja regulatornog okvira finansijskog izveštavanja Republike Srbije sa razvojem IFRS, zajedno sa opštim napomenama o načinima prevazilaženja varijacija u primeni IFRS, nagoveštava mogućnosti za unapređenje primene IFRS u RS u budućnosti. Regulatori finansijskog izveštavanja u RS treba da se staraju o ažurnom prevođenju svih relevantnih
IASB-ovih dokumenata, uz stalno preispitivanje i unapređivanje kvaliteta prevoda, kao i da neprestano jačaju mehanizme disciplinovanja revizora. Takođe, nacionalni regulatori treba da nastoje da se uzdržavaju od donošenja propisa kojima se modifikuju odredbe IFRS, a eventualne modifikacije treba vršiti samo $u$ slučaju krajnje nužnosti. Računovodstvena profesija treba da radi na kontinuiranom unapređenju programa stručnog usavršavanja računovođa, uz stavljanje akcenta na adekvatno razumevanje konceptualnih osnova finansijskog izveštavanja na bazi IFRS. Regulatori i računovodstvena profesija treba da se, u meri u kojoj je to moguće, aktivno uključe $u$ proces razvoja IFRS, prevashodno kroz komentarisanje nacrta standarda i tumačenja, a u slučaju bilo kakvih nedoumica u vezi sa odredbama već donetih IFRS, oni treba da se obrate IASB-u.

Istraživanja $u$ ovom radu pretežno su fokusirana na sagledavanje širine prostora za nacionalne varijacije $\mathrm{u}$ primeni IFRS, što predstavlja glavno ograničenje rada. Stoga bi stvarne varijacije finansijskih izveštaja kompanija iz različitih zemalja koje se deklarišu kao sledbenice IFRS mogle da predstavljaju predmet budućih istraživanja u ovom području. S obzirom na to da je posebna pažnja u radu posvećena ugradnji IFRS u regulatorni okvir RS, stepen uporedivosti finansijskih izveštaja kompanija iz RS sa finansijskim izveštajima kompanija iz drugih zemalja koje su usvojile IFRS, i problemi sa kojima se računovođe iz RS suočavaju primenjujući IFRS, takođe, predstavljaju potencijalne predmete narednih istraživanja.

\section{REFERENCE}

Abd-Elsalam, O. H., \& Weetman, P. (2003). Introducing International Accounting Standards to an emerging capital market: relative familiarity and language effect in Egypt. Journal of International Accounting, Auditing and Taxation, 12(1), 63-84. doi: 10.1016/S1061-9518(03)00002-8.

Alali, F., \& Cao, L. (2010). International financial reporting standards - credible and reliable? An overview. Advances in Accounting, incorporating Advances in International Accounting, 26(1), 79-86. doi: 10.1016/j.adiac.2010.02.001.

Alfredson, K., Leo, K., Picker, R., Pacter, P., Radford, J., \& Wise, W. (2007). Applying International Financial Reporting Standards. Milton, Australia: John Wiley \& Sons Australia, Ltd. 
Amiraslani, H., Iatridis, G. E., \& Pope, P. F. (2013). Accounting for asset impairment: a test for IFRS compliance across Europe. London, UK: Centre for Financial Analysis and Reporting Research, Cass Business School.

Armstrong, C. S., Barth, M. E., Jagolinzer, A. D., \& Riedl, E. J. (2010). Market Reaction to the Adoption of IFRS in Europe. The Accounting Review, 85(1), 31-61. doi: 10.2308/ accr.2010.85.1.31.

Bogicevic, J. (2013). Accounting implications of foreign currency transactions translation and hedging. Economic Horizons, 15(2), 137-151. doi:10.5937/ekonhor1302133B.

Cabrera, L. (2008). Widespread Acceptance of IFRS Continues: Is It Time for U.S. Companies to Prepare for the Transition? The CPA Journal, 78(3), 36-37.

Deloitte (2008). 2008 IFRS Survey: Where Are We Today? Deloitte Development LLC.

Deloitte Global Services Limited. (2014). IAS 27 - Separate Financial Statements. Retrieved October 13, 2014, from http:// www.iasplus.com/en/standards/ias/ias27-2011\#aug2014.

Doupnik, T., \& Perera, H. (2007). International Accounting. International Edition. New York, USA: McGraw-Hill.

Doupnik, T., \& Richter, M. (2004). The Impact of Culture on the Interpretation of "In Context" Verbal Probability Expressions. Journal of International Accounting Research, 3(1), $1-20$

Epstein, B. J. (2009). The Economic Effects of IFRS Adoption. The CPA Journal, 79(3), 26-31.

Ernst \& Young (2012). Consistency in IFRS - no borders, one language: dream or reality? IFRS Outlook. UK: EYGM Limited.

IFRS Foundation (2012). IFRSs as the Global Standards: Setting a Strategy for the Foundation's Second Decade. London, UK: IFRS Fondation.

IFRS Foundation (2014). Jurisdiction Profiles. Retrieved June 3, 2014, from http://www.ifrs.org/Use-around-the-world/ Pages/Jurisdiction-profiles.aspx.

KPMG \& von Keitz, I. (2006). The Application of IFRS: Choices in Practice. UK: KMPG IFRG Limited.

Kvaal, E., \& Nobes, C. (2010). International differences in IFRS policy choice: a research note. Accounting and Business Research, 40(2), 173-187.

McGee, R. W. (2006). Adopting and Implementing International Financial Reporting Standards in Transition Economies. In G. N. Gregoriou, \& Gaber M. (Eds.), International Accounting:
Standards, Regulations, and Financial Reporting (pp. 199-223). Oxford, UK: Elsevier.

Nobes, C. (2013). The continued survival of international differences under IFRS. Accounting and Business Research, 43(2), 83-111. doi: 10.1080/00014788.2013.770644.

Nobes, C., \& Parker, R. (2010). Comparative International Accounting. Harlow, UK: Pearson Education Limited.

Pacter, P. (2013). What Have IASB and FASB Convergence Efforts Achieved? Journal of Accountancy, 215(2), 50-59.

Pacter, P. (2014). Global Accounting Standards - From Vision to Reality: Assessing the State of IFRS Adoption, Jurisdiction by Jurisdiction. The CPA Journal, 84(1), 6-10.

PricewaterhouseCoopers (2007a). International Financial Reporting Standards: The right move for US business. 10 Minutes on IFRS. Delaware, USA: PricewaterhouseCoopers LLP.

PricewaterhouseCoopers (2007b). ViewPoint: Convergence of IFRS and US GAAP. London, UK: PricewaterhouseCoopers.

PricewaterhouseCoopers (2010). IFRS adoption by country. Delaware, USA: PricewaterhouseCoopers LLP.

Saudagaran, S. M. (2009). International Accounting: A User Perspective. Chicago, USA: CCH.

Securities and Exchange Commission (2010). Commission Statement in Support of Convergence and Global Accounting Standards. Release Nos. 33-9109; 34-61578. Washington, USA: U.S. Securities and Exchange Commission.

Stevenson, K. M. (2008). The IASB: Some Personal Reflections. In J. M. Godfrey, \& Chalmers, K. (Eds.), Globalisation of Accounting Standards (pp. 34-45). Cheltenham, UK: Edward Edgar.

Tokar, M. (2005). Convergence and the Implementation of a Single Set of Global Standards: The Real-life Challenge. Accounting in Europe, 2, 48-68.

Whittington, G. (2008). Harmonisation or discord? The critical role of the IASB conceptual framework review. Journal of Accounting and Public Policy, 27(6), 495-502. doi: 10.1016/j. jaccpubpol.2008.09.006

Willemain, J. (2008). Corporate reporting: Trends and tensions in convergence. Deloitte.

Zeff, S. A. (2007). Some obstacles to global financial reporting comparability and convergence at high level of quality. The British Accounting Review, 39(4), 290-302. doi: 10.1016/j. bar.2007.08.001. 
Primljeno 22. avgusta 2014, nakon revizije,

prihvaćeno za publikovanje 15. decembra 2014.

Elektronska verzija objavljena 22. decembra 2014.

Vladimir Obradović je docent na Ekonomskom fakultetu Univerziteta u Kragujevcu, na kome je i doktorirao. Obavlja nastavne aktivnosti na nastavnim predmetima: Finansijsko izveštavanje, Specijalni bilansi, Međunarodno finansijsko izveštavanje, iz uže naučne oblasti Računovodstvo, revizija i poslovne finansije. Njegova naučna interesovanja prevashodno su vezana za međunarodne aspekte i standarde finansijskog izveštavanja.

\title{
INCONSISTENT APPLICATION OF INTERNATIONAL FINANCIAL REPORTING STANDARDS
}

\author{
Vladimir Obradovic \\ Faculty of Economics, University of Kragujevac, Kragujevac, Serbia
}

The transformation of the International Financial Reporting Standards (IFRS) into a single global language of financial reporting is well under way and followed by a problem of their inconsistent application from country to country, with negative consequences for the global comparability of financial statements. Starting from this, the main purpose of this paper is to give an overview of the main causes of the diversity of financial reporting practices between those countries declaring themselves to be the followers of the IFRS, as well as to identify the ways of overcoming this diversity. Applying the qualitative research methodology, it has been found that the flexibility of the IFRS provisions, which is inevitable in many cases, modifications in their incorporation into national regulatory frameworks and the diversity and unequal effectiveness of national mechanisms for their enforcement and the supervision of their implementation stand for the main causes of inconsistent accounting practices. In order to reduce the inconsistency, national financial reporting regulators should increase their engagement and coordination among themselves, and the International Accounting Standards Board should make additional efforts, which should primarily be focused on the global promotion of the fundamental basis of the IFRS.

Keywords: financial reporting, International Financial Reporting Standards (IFRS), International Accounting Standards Board (IASB), inconsistent application 